\begin{tabular}{ccc}
\hline bentham open & Clinical Practice \& Epidemiology in \\
CrossMark & Mental Health \\
\hline
\end{tabular}

RESEARCH ARTICLE

\title{
Internet Addiction and Excessive Social Networks Use: What About Facebook?
}

\author{
Eduardo Guedes ${ }^{1,2,3}$, Federica Sancassiani ${ }^{4}$, Mauro Giovani Carta ${ }^{4}$, Carlos Campos ${ }^{2,5}$, Sergio \\ Machado $^{2,6, *}$, Anna Lucia Spear King ${ }^{1,2}$ and Antonio Egidio Nardi ${ }^{1,2}$ \\ ${ }^{1}$ Grupo Delete - Detox Digital e uso consciente de Tecnologias, Rio de Janeiro, Brazil \\ ${ }^{2}$ Laboratory of Panic and Respiration, Institute of Psychiatry (IPUB), Federal University of Rio de Janeiro (UFRJ), \\ Rio de Janeiro, Brazil \\ ${ }^{3}$ College of Social Communication, Pontifícia Universidade Católica (PUC), Rio de Janeiro, Brazil \\ ${ }^{4}$ Department of Public Health, Clinical and Molecular Medicine, University of Cagliari, Cagliari, Italy \\ ${ }^{5}$ Polytechnic Institute of Porto, Health School, Porto, Portugal \\ ${ }^{6}$ Physical Activity Neuroscience, Physical Activity Postgraduate Program, Salgado de Oliveira University \\ (UNIVERSO), Niterói, Brazil
}

\begin{abstract}
Facebook is notably the most widely known and used social network worldwide. It has been described as a valuable tool for leisure and communication between people all over the world. However, healthy and conscience Facebook use is contrasted by excessive use and lack of control, creating an addiction with severely impacts the everyday life of many users, mainly youths. If Facebook use seems to be related to the need to belong, affiliate with others and for self-presentation, the beginning of excessive Facebook use and addiction could be associated to reward and gratification mechanisms as well as some personality traits. Studies from several countries indicate different Facebook addiction prevalence rates, mainly due to the use of a wide-range of evaluation instruments and to the lack of a clear and valid definition of this construct. Further investigations are needed to establish if excessive Facebook use can be considered as a specific online addiction disorder or an Internet addiction subtype.
\end{abstract}

Keywords: Excessive Use, Facebook, Internet Addiction, Social Networks.

\section{RATIONALE}

In the last decade, the large availability of the internet and the embracing of new digital technologies like smartphones are changing people's way of life and introducing new social dynamics [1 - 7]. Social networks allow immediate communication with just one click, by searching, reaching and sending any kind of verbal messages, videos or images. Thus, the use of social networks facilitates virtual contacts and meetings with other people, replacing many personal relationships and commitments [1 - 5]. With its 1.4 billion active users, Facebook is now considered the most popular social network worldwide $[8,9]$ and, as a consequence, researchers have started to study some features of its use $[10,11]$, as well as its excessive use $[12,13]$. Caplan developed an overall theory about the misuse of the internet, according to which an online communication type allows to avoid negative feelings, such as loneliness and anxiety [14, $15]$.

Griffiths stated that an addictive behavior is characterized by the six core components of addiction: salience, mood modification, tolerance, withdrawal symptoms, conflict, and relapse [16, 17]. He argued that any behavior that fulfills

\footnotetext{
* Address correspondence to this author at Laboratory of Panic and Respiration, Institute of Psychiatry (IPUB), Federal University of Rio de Janeiro (UFRJ), Rio de Janeiro, Brazil; E-mail: secm80@gmail.com
} 
these six criteria can be considered as an addiction, including social networking. Furthermore, the addiction on social networks, as Facebook, has also been considered only when the excessive use damages personal, family and/or professional life $[18,19]$. Some reports indicate that the excessive use of social networks increases isolation in real life, bringing harms to relationships [20]. It is worthily highlighted that a growing complaint in mental health services from patients or even parents worried about their children's is increased social isolation, levels of anxiety and worsening in school performance due to excessive social networks use [21].

Griffiths described the Social Network Sites (SNSs) addiction by 6 pillars: usage patterns, motivations, dependency and typical profiles, negative consequences, evidence of dependence and comorbidity [17, 22]. Furthermore, there is also a review evaluating SNSs addiction in 17 studies which shows a growing interest on this issue, although findings are limited because of the methodology used [23]. As a result, internet addiction and social networks addiction are not well-defined constructs yet, mainly because there is no gold standard measures of these conditions, nor is there any widely accepted theory $[4,12]$. On the other hand, some authors [5, 24, 25] introduced specifically the "Facebook Addiction Disorder", or more generally "SNSs Addiction Disorder", on the basis of these six addiction criteria: (1) neglect of personal life; (2) mental preoccupation; (3) escapism (an entertainment that allows people to forget about the real problems of life); (4) mood modifying experiences; (5) tolerance and (6) concealing the addictive behavior.

Despite many researchers defending the hypothesis that the excessive use of the internet and social networks as Facebook can cause addiction, the concept is still controversial [5, 12, 17, 23, 26, 27] and the DSM-5 [21] did not include them as addiction disorders. Within this context, the aim of the present paper is to summarize the state of the art about the use and excessive use of Facebook and to explore how Facebook usage could become addictive.

\section{FACEBOOK USE AND EXCESSIVE USE}

Statistics provided by Facebook in 2015 [9] reveal that, worldwide, there are over 1.44 billion monthly active Facebook users and at least 936 million people log in every day. Among those daily users, 745 million check the site by their mobile devices. According to a recent review, there are cultural and socio-demographic differences in Facebook use: females and ethnic minorities seem to use Facebook more than males and Caucasians [10]. Furthermore, a cross-culture study examined differences in Facebook use among people from USA, UK, Italy, Greece and France, founding that, compared to USA users, the UK users classified "groups" as being more relevant, Italian users rated both "groups" and "games/applications" as most relevant, whereas Greek users considered "status updates" being less relevant [28].

A recent study on 100 Swedish students about the use of Facebook shows that $85 \%$ of them log in Facebook at least one time every day and 70\% admitted that they logged in whenever they started their computer [29]. Furthermore, the participants spent an average of 75 minutes a day on Facebook, with men spending 64 minutes and women 81 minutes every day. In this study, the average user logs in on Facebook 6.1 times/day and almost half the participants mentioned that they feel it is hard to keep up socially without Facebook. Another survey conducted on a sample of 1605 US adults aged between 18 and 54 years old, shows that 34\% of girls aged between 18-34 log in to Facebook before they go to the toilet every time they wake up in the morning, $21 \%$ wake up in the middle of the night to read their texts and $39 \%$ identify themselves as Facebook addicts [30]. Furthermore, Hofmann and colleagues [31], in a survey on 205 German Facebook and Twitter users aged between 18 and 85, showed that the desire for being daily on social networks reported by participants is superior to the desires for sleep and rest. They concluded that social networks addiction is more harmful than smoking and drug-addiction because social media are widely available and cheaper.

\section{HOW FACEBOOK COULD BECOME ADDICTIVE?}

Even with an increasing amount of evidence focusing on social network addiction [8] and a few studies indicating that the prevalence of Facebook addiction ranges from $8.6 \%$ to $41.9 \%$ [12, 32 - 34], limited research has examined how Facebook use could become addictive [17, 23]. The "biopsychosocial framework" for the etiology of addictions [16] and the "syndrome model of addiction" [35] state that people addicted to social networks have similar symptoms to those reported by people who suffer from substances addiction [36]. Xu and Tan [37] proposed that the shift from normal to social networking misuse arises when social networking is considered as an important (or even exclusive) instrument to cope with stress, loneliness and depression.

Regarding Internet addiction, Griffiths [23] argued that it is not well established if people become addicted to the platform or to the contents of the internet. Users addicted to the internet cannot give up several aspects of online use. 
Thereby, the author postulates three subtypes of internet addicts, on the basis of the "object" of the addiction: on-line games, sex, and e-mail or text messages. Social networks are an online activity in which texting or e-mailing are predominant, in spite of being used for game playing and even sex-related purposes.

According to the model proposed by Nadkami and Hofman [10], Facebook use is mainly driven by two basic social needs: (1) sense of belonging to, and (2) self-presentation. The "need to belong" arises from the basic drive to affiliate with others and obtain social acceptance, whereas the need for self-presentation is steadily required for the process of impression management. These motivational drives often co-exist and could explain the Facebook use. Several demographic and cultural factors are associated with the need to belong, whereas personality traits such as neuroticism, narcissism, shyness, self-esteem and self-worth are associated with the need for self-presentation.

Tamir and Michell [38] described an increased neural activation underling the cognitive mechanisms associated with gratification upon talking about oneself. Using fMRI, the authors explored how brain activity while people talked about themselves was related to a pleasant experience, in comparison to other natural rewards such as sex or food. Authors argued that babies aged 9 months try to catch other's attention to the parts of the environment that they view as the most important, which could be considered the first form of self-exposure; adults, on the other hand, want to give forward information to others about themselves. Thus, human beings have an intrinsic drive for self-exposure, and this behavioral pattern is forced in social networks because of the brain's reward system: "People dedicate close to $40 \%$ of their time talking about themselves. This number reaches $80 \%$ in social networks with the possibility of feedback and immediate rewards" [38].

Similarly to many addictions, the activation of the reward system through self-exposure $[39,40]$ can increase the level of dopamine in the reward system [41], generating a dependence framework for social networks excessive use. Finally, some studies $[17,23]$ evaluated the tendency to develop a social network addiction based on personality traits such as: "extroversion", "socialization", "awareness", "neuroticism" and "openness to experimentation". Furthermore, the potential excessive use of social networks seems to be related to high narcissism, high neuroticism and low awareness $[5,42]$.

\section{MEASURING INTERNET ADDICTION AND FACEBOOK ADDICTION}

Several authors attempted to define Internet addiction as a syndrome with a set of symptoms that includes: a) preoccupation with the Internet activities; b) increasing tolerance; c) development of psychological dependency and withdrawal symptoms; d) inability to reduce Internet use; e) Internet use to cope with negative mood and reduce stress; f) replacing other activities and relationships with recurrent Internet use despite awareness of the bad consequences [43 - 45]. The Internet Addiction Scale [46], a 20 item self-report questionnaire, is a revised version of the earlier 8 item scale Young's Internet Addiction Diagnostic Questionnaire [43] and it was developed by adapting DSM-IV criteria for pathological gambling, a diagnosis classified as an impulse-control disorder.

Actually, this instrument is the most widely used alternative in the field of internet addiction [47] and it measures the degree to which all types of online activities disturbs aspects of one's daily life: daily routine, sleep pattern, productivity, social life, feelings. With regards to Facebook addiction, the systematic review of Ryan and colleagues [12] analyzed eight self-report questionnaires used to its evaluation in several studies [8, 48 - 53]. Authors concluded that research addressing this salient area is still in its infancy and highlighted the overall lack of construct validity surrounding these instruments, developed from existing measures of Internet addiction without in-depth exploratory research with Facebook addicted individuals [12].

\section{CONCLUSION AND FUTURE PERSPECTIVES}

Internet addiction and excessive social networks use are already important issues for treatment and research. Even if Facebook is the number one tool to promote entertainment, maintaining relationships and occupying time [40], some people could develop addictive behavior based on the sensation to feel better or more self-assured (increased level of excitement or escape) upon navigating social networks [54]. Facebook addiction could be related to brain reward and gratification mechanisms and it seems more prevalent in persons with some personality traits and mood states, such as anxiety, depression, narcissism, low self-esteem, seeking for an increased mood elevation.

Despite being a current topic, Internet addiction and excessive social networks use could be unnoticed and underestimated. However, specialized clinics and programs already target these kinds of addictions [55] although there is still a need for further research to determine if Facebook excessive use can be considered as a specific online 
addiction disorder or an Internet addiction subtype.

\section{CONFLICT OF INTEREST}

The authors confirm that this article content has no conflict of interest.

\section{ACKNOWLEDGEMENTS}

Declared none.

\section{REFERENCES}

[1] Boyd DM, Ellison NB. Social network sites: Definition, history, and scholarship. J Comput Mediat Commun 2007; $13(1)$ : $210-30$. [http://dx.doi.org/10.1111/j.1083-6101.2007.00393.x]

[2] Ellison NB, Steinfield C, Lampe C. The benefits of Facebook "friends": Social capital and college students' use of online social network sites. J Comput Mediat Commun 2007; 12(4): 1143-68. [http://dx.doi.org/10.1111/j.1083-6101.2007.00367.x]

[3] Cheung CM, Chiu P, Lee MK. Online social networks: why do students use Facebook? Comput Human Behav 2011; 27(4): 1337-43. [http://dx.doi.org/10.1016/j.chb.2010.07.028]

[4] Kuss DJ, Griffiths MD, Karila L, Billieux J. Internet addiction: a systematic review of epidemiological research for the last decade. Curr Pharm Des 2014; 20(25): 4026-52.

[http://dx.doi.org/10.2174/13816128113199990617] [PMID: 24001297]

[5] Kuss DJ, Griffiths MD. Online social networking and addiction-a review of the psychological literature. Int J Environ Res Public Health 2011; 8(9): 3528-52. [http://dx.doi.org/10.3390/ijerph8093528] [PMID: 22016701]

[6] King AL, Valença AM, Silva AC, Sancassiani F, Machado S, Nardi AE. "Nomophobia": impact of cell phone use interfering with symptoms and emotions of individuals with panic disorder compared with a control group. Clin Pract Epidemol Ment Health 2014; 10 : 28-35. [http://dx.doi.org/10.2174/1745017901410010028] [PMID: 24669231]

[7] King AL, Valença AM, Silva AC, Baczynski T, Carvalho MR, Nardi AE. Nomophobia: dependency on virtual enviroments or social phobia? Comput Human Behav 2013; 29(140-144)

[8] Cam E, Isbulan O. A new addiction for teacher candidates: Social networks. Turk Online J Educ Technol 2012; 11(3): 14-9.

[9] Facebook. Company info: Facebook newsroom: Facebook; 2015. Available from: http://newsroom.fb.com/company-info/ 2015.

[10] Nadkarni A, Hofmann SG. Why do people use Facebook? Pers Individ Dif 2012; 52(3): 243-9. [http://dx.doi.org/10.1016/j.paid.2011.11.007] [PMID: 22544987]

[11] Wilson RE, Gosling SD, Graham LT. A review of facebook research in the social sciences. Perspect Psychol Sci 2012; 7(3): 203-20. [http://dx.doi.org/10.1177/1745691612442904] [PMID: 26168459]

[12] Ryan T, Chester A, Reece J, Xenos S. The uses and abuses of Facebook: A review of Facebook addiction. J Behav Addict 2014 ; 3(3): 133-48. [http://dx.doi.org/10.1556/JBA.3.2014.016] [PMID: 25317337]

[13] Weinstein A, Lejoyeux M. Internet addiction or excessive internet use. Am J Drug Alcohol Abuse 2010; 36(5): $277-83$. [http://dx.doi.org/10.3109/00952990.2010.491880] [PMID: 20545603]

[14] Caplan SE. Relations among loneliness, social anxiety, and problematic Internet use. Cyberpsychol Behav 2007; 10(2): 234-42. [http://dx.doi.org/10.1089/cpb.2006.9963] [PMID: 17474841]

[15] Caplan SE. Theory and measurement of generaliz ed problematic Internet use: A two-step approach. Comput Human Behav 2010; 26(5): 1089-97. [http://dx.doi.org/10.1016/j.chb.2010.03.012]

[16] Griffiths MD. A 'components' model of addiction within a biopsychosocial framework. J Subst Abuse 2005; $10(4): 191-7$.

[17] Griffiths MD. Social networking addiction: Emerging themes and issues. J Addict Res Ther 2013; 4 : e118. [http://dx.doi.org/10.4172/2155-6105.1000e118]

[18] LaRose R, Kim J, Peng W. Social Networking: Addictive, Compulsive, Problematic, or Just Another Media Habit? In: Papacharissi Z, Ed. A networked self: Identity, community, and culture on social network sites. New York: Taylor \& Francis 2010.

[19] LaRose R, Mastro D, Eastin MS. Understanding Internet usage: A social-cognitive approach to uses and gratifications. Soc Sci Comput Rev 2001; 19(4): 395-413.

[http://dx.doi.org/10.1177/089443930101900401]

[20] Elphinston RA, Noller P. Time to face it! Facebook intrusion and the implications for romantic jealousy and relationship satisfaction. Cyberpsychol Behav Soc Netw 2011; 14(11): 631-5. [http://dx.doi.org/10.1089/cyber.2010.0318] [PMID: 21548798]

[21] American Psychiatric Association. Diagnostic and Statistical Manual of Mental Disorders. $5^{\text {th }}$ ed. Arlington, VA: APA 2013. 
[22] Griffiths MD. Facebook addiction: concerns, criticism, and recommendations-a response to Andreassen and colleagues. Psychol Rep 2012; 110(2): 518-20. [http://dx.doi.org/10.2466/01.07.18.PR0.110.2.518-520] [PMID: 22662405]

[23] Griffiths MD, Kuss DJ, Demetrovics Z. Social networking addiction: An overview of preliminary findings. In: Rosenberg KP, Feder C, Eds. Behavioral addictions: Criteria, evidence, and treatment. London: Academic Press 2014; pp. 119-41. [http://dx.doi.org/10.1016/B978-0-12-407724-9.00006-9]

[24] Young K. Facebook Addiction Disorder?. Bradford, PA, USA: The Center for Online Addiction 2009.

[25] Summers A. Facebook Addiction Disorder - The 6 Symptoms of F.A.D: Social Times; 2011. Available from: http://www.adweek.com/ socialtimes/facebook-addiction-disorder-the-6-symptoms-of-f-a-d/61408?red=st

[26] Pies R. Should DSM-V Designate “Internet Addiction” a Mental Disorder? Psychiatry (Edgmont) 2009; 6(2): 31-7. [PMID: 19724746]

[27] Song I, LaRose R, Eastin MS, Lin CA. Internet gratifications and internet addiction: on the uses and abuses of new media. Cyberpsychol Behav 2004; 7(4): 384-94.

[http://dx.doi.org/10.1089/cpb.2004.7.384] [PMID: 15331025]

[28] Vasalou A, Joinson AN, Courvoisier D. Cultural differences, experience with social networks and the nature of "true commitment" in Facebook. Int J Hum Comput Stud 2010; 68(10): 719-28. [http://dx.doi.org/10.1016/j.ijhcs.2010.06.002]

[29] Denti L, Barbopuolos I, Nilsson I, et al. Sweden's largest Facebook study. Gothenburg: University of Gothenburg 2012.

[30] Abhijit N. Facebook Addiction. USA: Buzzle; 2012 Available from: http://www.buzzle.com/articles/facebook-addiction.html 2012.

[31] Hofmann W, Vohs KD, Baumeister RF. What people desire, feel conflicted about, and try to resist in everyday life. Psychol Sci 2012; 23(6): $582-8$. [http://dx.doi.org/10.1177/0956797612437426] [PMID: 22547657]

[32] Wolniczak I, Cáceres-DelAguila JA, Palma-Ardiles G, et al. Association between Facebook dependence and poor sleep quality: a study in a sample of undergraduate students in Peru. PLoS One 2013; 8(3): e59087. [http://dx.doi.org/10.1371/journal.pone.0059087] [PMID: 23554978]

[33] Lee YL, Verma RK, Yadav H, Barua A. Health impacts of Facebook usage and mobile texting among undergraduate dental students: it's time to understand the difference between usage and an excessive use. Eur J Dent Educ 2015. [Epub ahead of print] [http://dx.doi.org/10.1111/eje.12164] [PMID: 26277860]

[34] Khumsri J, Yingyeun R, Mereerat Manwong, Hanprathet N, Phanasathit M. Prevalence of facebook addiction and related factors among thai high school students. J Med Assoc Thai 2015; 98(Suppl. 3): S51-60. [PMID: 26387389]

[35] Shaffer HJ, LaPlante DA, LaBrie RA, Kidman RC, Donato AN, Stanton MV. Toward a syndrome model of addiction: multiple expressions, common etiology. Harv Rev Psychiatry 2004; 12(6): 367-74. [http://dx.doi.org/10.1080/10673220490905705] [PMID: 15764471]

[36] Echeburúa E, de Corral P. Addiction to new technologies and to online social networking in young people: A new challenge. Adicciones 2010; 22(2): 91-5.

[PMID: 20549142]

[37] Xu H, Tan BC. Why do I keep checking Facebook: Effects of Message Characteristics on the Formation of Social Network Services Addiction. In: International Conference on Information Systems. Florida, USA: ICIS 2012.

[38] Tamir DI, Mitchell JP. Disclosing information about the self is intrinsically rewarding. Proc Natl Acad Sci USA 2012; $109(21)$ : 8038-43. [http://dx.doi.org/10.1073/pnas.1202129109] [PMID: 22566617]

[39] Chen HT, Kim Y. Problematic use of social network sites: the interactive relationship between gratifications sought and privacy concerns. Cyberpsychol Behav Soc Netw 2013; 16(11): 806-12.

[http://dx.doi.org/10.1089/cyber.2011.0608] [PMID: 24053383]

[40] Chen GM. Tweet this: A uses and gratifications perspective on how active Twitter use gratifies a need to connect with others. Comput Human Behav 2011; 27(2): 755-62. [http://dx.doi.org/10.1016/j.chb.2010.10.023]

[41] Schultz W. Getting formal with dopamine and reward. Neuron 2002; 36(2): 241-63. [http://dx.doi.org/10.1016/S0896-6273(02)00967-4] [PMID: 12383780]

[42] Panek ET, Nardis Y, Konrath S. Mirror or megaphone? How relationships between narcissim and social networking site use differ on Facebook and Twitter. Comput Human Behav 2013; 29(5): 2004-12. [http://dx.doi.org/10.1016/j.chb.2013.04.012]

[43] Young KS. Internet addiction: the emergence of a new clinical disorder. Cyberpsychol Behav 2009; 1(3): 237-44. [http://dx.doi.org/10.1089/cpb.1998.1.237]

[44] Spada MM. An overview of problematic internet use. Addict Behav 2014; 39(1): 3-6. [http://dx.doi.org/10.1016/j.addbeh.2013.09.007] [PMID: 24126206] 
[45] Li W, O’Brien JE, Snyder SM, Howard MO. Characteristics of internet addiction/pathological internet use in U.S. university students: a qualitative-method investigation. PLoS One 2015; 10(2): e0117372. [http://dx.doi.org/10.1371/journal.pone.0117372] [PMID: 25647224]

[46] Widyanto L, McMurran M. The psychometric properties of the internet addiction test. Cyberpsychol Behav 2004; 7(4): 443-50. [http://dx.doi.org/10.1089/cpb.2004.7.443] [PMID: 15331031]

[47] Boysan M, Kuss DJ, Barut Y, Ayköse N, Güleç M, Özdemir O. Psychometric properties of the Turkish version of the Internet Addiction Test (IAT). Addict Behav 2015; S0306-4603(15): 30013-7. [PMID: 26421905]

[48] Sofiah S, Omar SZ. J. B, Osman MN. Facebook addiction among female university students. Revista De Administratie Publica Si Politici Sociale 2011; 2(7): 95-109.

[49] Andreassen CS, Torsheim T, Brunborg GS, Pallesen S. Development of a facebook addiction scale. Psychol Rep 2012; $110(2)$ : 501-17. [http://dx.doi.org/10.2466/02.09.18.PR0.110.2.501-517] [PMID: 22662404]

[50] Lee ZW, Cheung CM, Thadani DR. An invesrigation into the problematic use of facebook. $45^{\text {th }}$ Hawaii International Conference on System Sciences; 2012 Jan 4-7; Maui, Hawaii: IEEE; 1768-76.

[51] Balakrishnan V, Shamim A. Malaysian Facebookers: Motives and addictive behaviours unraveled. Comput Human Behav 2013; 29(4): 1342-9. [http://dx.doi.org/10.1016/j.chb.2013.01.010]

[52] Koc M, Gulyagci S. Facebook addiction among Turkish college students: the role of psychological health, demographic, and usage characteristics. Cyberpsychol Behav Soc Netw 2013; 16(4): 279-84. [http://dx.doi.org/10.1089/cyber.2012.0249] [PMID: 23286695]

[53] Hong F, Huang D, Lin H, Chiu S. Analysis of the psychological traits, Facebook usage, and Facebook addiction model of Taiwanese university students. Telemat Inform 2014; 31(4): 597-606. [http://dx.doi.org/10.1016/j.tele.2014.01.001]

[54] Giannakos MN, Chorianopoulos K, Gioyopoulos K, Vlamos P. Using Facebook out of habit. Behav Inf Technol 2013; 32(6): 594-602. [http://dx.doi.org/10.1080/0144929X.2012.659218]

[55] Vishwanath A. Habitual facebook use and its impact on getting deceived on social media. J Comput Mediat Commun 2015; 20(1): 83-98. [http://dx.doi.org/10.1111/jcc4.12100]

(C) Guedes et al.; Licensee Bentham Open.

This is an open access articles licensed under the terms of the Creative Commons Attribution-Non-Commercial 4.0 International Public License (CC BY-NC 4.0) (https://creativecommons.org/licenses/by-nc/4.0/legalcode), which permits unrestricted, non-commercial use, distribution and reproduction in any medium, provided that the work is properly cited. 